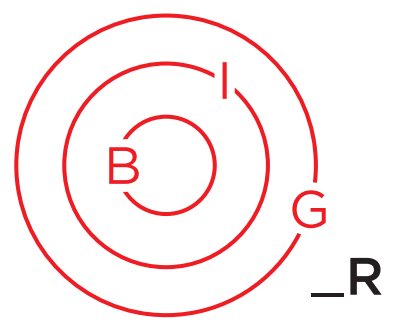

FILM REVIEW

\title{
Only Those Who Can Leave Are Allowed to Stay: Petzold's Masterful Adaptation of Seghers' Transit
}

\section{Marion Christina Rohrleitner*}

\begin{abstract}
Transit
2018

Director and screenwriter: Christian Petzold

Original Language: German

Runtime: 1 hour and 42 minutes

More information at IMDB
\end{abstract}

Based on Anna Seghers' eponymous 1944 novel, the film draws attention to one of the central contradictions inherent in immigration policy-how the temporal urgency refugees face conflicts with the bureaucratic inefficiency of the refugee settlement process, both then and now. In the summer of 1940, thousands of refugees from the Third Reich hoped to be granted immigrant visas to the Americas in Marseille; however, they also needed to obtain rare transit visas for the countries they were passing through on the way to their final destination. The endless time spent waiting in embassies, consulates, and transportation offices relegated human beings who had barely escaped concentration camps and Gestapo interrogations to a passivity alternatingly infused with longing and despair. Seghers began working on this novel, which was published in English and Spanish translations four years before appearing in the German original in 1948, aboard a ship from Marseille to her own exile in Mexico in 1941.

Transit is Christian Petzold's eighth feature and draws on several conventions of the noir genre. The film's main protagonist, Georg (played with aplomb by former dancer Franz Rogowksi), escaped a concentration camp and a

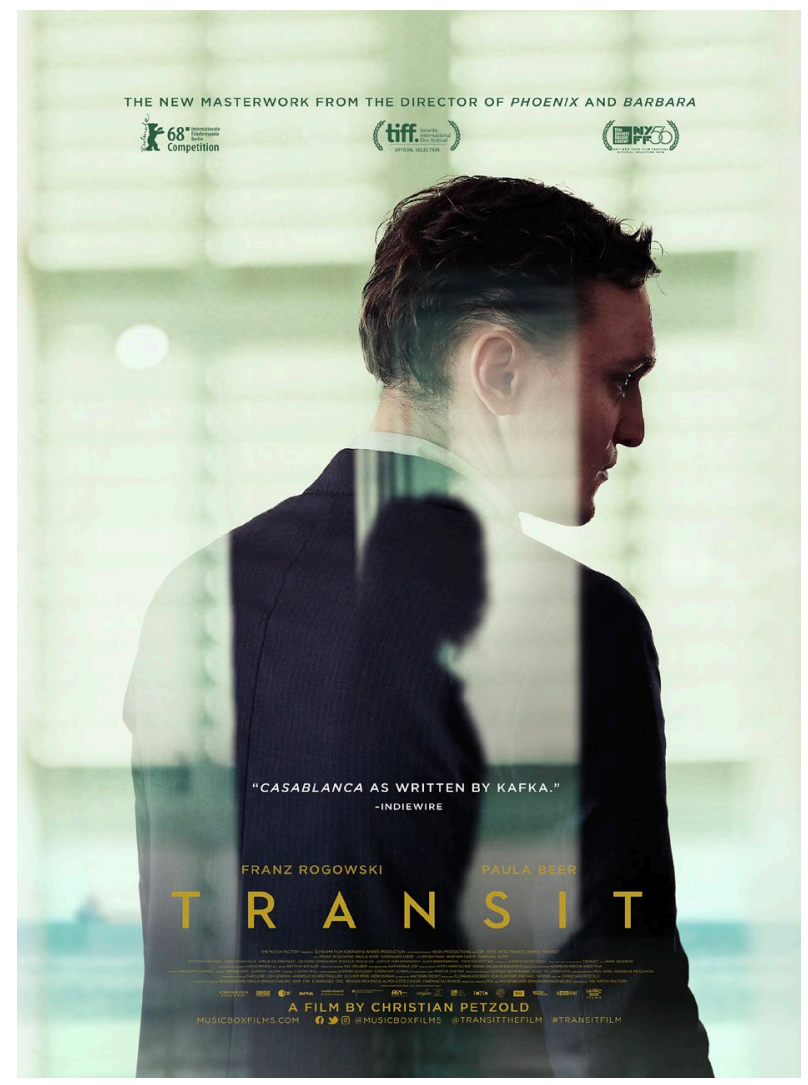

French prison, and made his way from occupied Paris to Marseille to deliver a package to the well-known exiled writer, Weidel. He is in the company of his friend Heinz (Ronald Kukulies), who hopes to reunite with his wife and son, but suffers a heart attack and dies on the train en route to Marseille. After learning of Weidel's suicide, Georg opens the package and finds the author's final

* Marion Christina Rohrleitner is Associate Professor of English at The University of Texas at El Paso and a specialist in contemporary Chicanx/Latinx and Caribbean diasporic literatures. 
manuscript, a transit visum, and a ticket for safe passage to Mexico. After the Mexican consul mistakes him for the writer, Georg is tempted to adopt Weidel's identity and to use his visum. This plan is complicated when Georg meets and falls in love with Marie (Paula Beer), Weidel's estranged wife, who arrives in Marseille with her lover Richard (Godehard Giese), in hopes of reconciling with her husband. Each protagonist's dependence on stateissued documents for survival rings familiar today, both in Fortress Europe and in a United States with increasingly militarized borders. In one of the key moments of the film, Georg comes to the realization that "only those who can prove they can leave are allowed to stay."

The director's decision to preserve plot, main characters, and dialogue from Seghers' novel while largely changing the setting to our contemporary moment-albeit without omnipresent smart phones-adds to the eerie, dreamlike quality of the profound disorientation refugees are experiencing while they do what all refugees have to do for inconceivable amounts of time: wait. There is a viscous quality to this imposed wait; a powerlessness that can neither be subdued by the gritty beauty of the Southern French city nor by glasses of rosé or countless shots of espresso or through infatuation with an enigmatic woman. The voice-over, powerfully delivered by Matthias Brandt in the role of a bartender who is the confidante of his troubled customers, offers an intimacy that successfully translates the novel's second person narrative perspective for the screen. The film's soundtrack is kept to a minimum, the frequent silences adding a sonic dimension to the refugees' endless wait. The rich tones of the French coastal city contrast with the frigid terror of a bureaucracy that decides who will get transit visa and live, and who will be denied and likely be deported to a concentration camp.

There could not be a more foreboding setting for novel and film than Marseille. In 1940 it was a cultural crossroads; the city's ongoing liminality makes it an ideal locale for a film set simultaneously in 1940 and 2018. Petzold's adaptation stays true to Seghers' plot and character development while never identifying the oppressive force as Nazi Germany and depicting a contemporary Marseille filled not only with European but also Middle Eastern and African refugees. In doing so, the director ingeniously links the plight of Jewish and political refugees from the Third Reich with the dire fate of refugees fleeing the war in Syria, and those escaping abject poverty, environmental catastrophes, and dictatorships in North and Central Africa. The condition of the refugee is characterized as being stuck in perpetual limbo; having defied the death machinery in their countries of origin, they are now condemned to wait for the bureaucratic machinery to grant them status and the possibility of survival. Their presence embodies the permanence of the refugee crisis as a result of colonialism, fascism, and global capitalism.

If I were to find one flaw in this otherwise exceptional film, it would be the anachronistic passivity of Marie Weidel. Paula Beer, a German actress who played a fictionalized version of Gerhard Richter's wife in Never Look Away and a modern siren in Petzold's recent Undine, is reminiscent, perhaps intentionally, of Ingrid Bergman's Ilsa Lund in Casablanca, and more out of place and time than the French police in 21st century riot gear. Marie drifts in and out of the frame of the film just as she drifts in and out of Georg's life; she resembles a specter more than a living, breathing woman in the flesh.

In a recent interview Petzold called Marseille a "city of desire", and it is there where Georg reads his first book, falls in love, and becomes a father figure for Driss, Heinz's son. In the film, the boy is biracial, his mother a deaf, undocumented migrant from the Maghreb; France's colonial history, especially its abject brutality in Algeria, looms large, as does the racialized violence in the banlieues of Emmanuel Macron's and Marie Le Pen's contemporary France. It is Petzold's uncanny ability to seamlessly connect the horrors of enforcing national and racial borders in Vichy's France with those of Fortress Europe in the 21st century that make his film a timely and critical contribution to current debates about human rights and migration.

\section{Work Cited}

Anna Seghers. 1944/1948. Transit. 